\title{
Analisis Pohon Filogenik dari Protein Non-Struktural 1 (NS1) Virus Dengue di Kawasan Asia Tenggara
}

\author{
Vanny Narita ${ }^{12 *}$, Asma Omar $^{1}$, Agus Masduki $^{3}$ \\ ${ }^{1}$ Program Studi Biologi (Bioteknologi), Fakultas Sains dan Teknologi, \\ Universitas Al Azhar Indonesia, Jl. Sisingamangaraja, Jakarta 12110, \\ ${ }^{2}$ Pusat Teknologi Farmasi dan Medika, Badan Pengkajian dan Penerapan Teknologi, \\ Jl. MH Thamrin No. 8, Jakarta 10340 \\ ${ }^{3}$ Pusat Teknologi Bioindustri, Badan Pengkajian dan Penerapan Teknologi, \\ Jl. MH Thamrin No. 8, Jakarta 10340 \\ "Penulis untuk korespondensi: vnarita2000@yahoo.com
}

\begin{abstract}
Abstrak - Protein non-struktural 1 adalah protein Virus Dengue yang terkonservasi, tetapi protein non-struktural 1 dari Virus Dengue yang berbeda strain memiliki epitop berbeda yang dapat dikenali oleh sel-B. Epitop-epitop ini mungkin disusun oleh asam amino yang sama dalam urutan yang berbeda. Kemungkinan ini perlu dipertimbangkan dalam rangka memprediksi epitop sekuensial Virus Dengue. Tujuan penelitian kami adalah menganalisis hubungan kekerabatan dan susunan asam amino pada epitop spesifik yang telah dikonfirmasi dari sampel representatif gen protein NS1 dari Virus Dengue di kawasan Asia Tenggara. Hubungan kekerabatan protein nonstruktural 1 dianalisis dengan perangkat lunak Lasergene $^{\circledR}$. Sekuen gen ditranslasi terlebih dahulu ke urutan asam amino, dan analisis pohon filogenetik kemudian dilakukan. Hasilnya menunjukkan bahwa hubungan kekerabatan protein non-struktural 1 berkisar antara 7298\%. Selanjutnya, epitop serospesifik dibandingkan berdasarkan hasil pengolahan data dnegan Lasergene. Perbandingan epitop serospesifik menunjukkan bahwa asam amino yang dominan dalam epitop adalah histidin, tirosin, glutamine dan serin
\end{abstract}

Abstract - Non-structural 1 protein is a conserved protein of dengue virus, but nonstructural 1 proteins of dengue virus from different strains have different epitopes which can be recognized by B-cell. These epitopes may be constructed of similar amino acids in a different arrangement. This possibility must be considered in order to predict the sequencial epitope of dengue virus. The objective of our study was to analyze the phylogenetic relation and the arrangment of confirmed specific epitopes of dengue strains from representatives of South East Asia's NS1 dengue gene samples. The phylogenetic relation of non-structural 1 protein sequences from South East Asia was analyzed with Lasergene ${ }^{\circledR}$ software. The gene sequences were translated to amino acid sequences, and phylogenetic tree analysis was performed. The results showed that the relatedness values among full sequences of nonstructural 1 protein were $\mathbf{7 2 - 9 8 \%}$. Furthermore, the serospesific epitopes were compared according to the Lasergene results. The serospesific epitope comparation showed that the dominant amino acids in these epitopes were histidine, tyrosine, glutamine and serine.

Keywords - Virus Dengue, non-struktural 1, sekuen, filogenetik, epitop sekuensial

\section{PENDAHULUAN}

$\mathrm{D}$ emam Dengue adalah penyakit yang disebabkan oleh infeksi Virus Dengue. Gejala yang muncul akibat serangan virus ini dapat berupa demam dengue (DB) hingga demam disertai pendarahan atau disebut demam berdarah dengue (DBD). Pada demam berdarah dengue, penderita mengalami permeabilitas kapiler, kelainan hemostasis dan pada kasus berat disertai sindrom syok kehilangan protein atau disebut sindrom syok dengue (DSS) [1]. Bahkan DHF dapat kasus mengakibatkan kematian penderitanya [2]. 
Data WHO [3] menunjukkan bahwa dengue adalah infeksi virus dengan vektor nyamuk yang paling cepat menyebar. Dalam jangka waktu 50 tahun, kasus dengue bertambah 30 kali lipat dengan \pm 50 juta kasus terjadi pada tahun 2007 (gambar 1). Menurut data WHO epidemiologi dengue mencakup negara-negara kawasan Asia (Asia Tenggara dan Pasifik Barat), Amerika (Amerika Selatan, Amerika Utara, Adean, Amerika Tengah, Meksiko, dan Karibia), Afrika (Afrika Timur dan Afrika Barat) dan kawasan Mediterania Timur serta negara gurun.

Akibat dampak meluas yang ditimbulkan penyakit ini, The 2002 World Health Assembly membuat resolusi WHA55 untuk meningkatkan komitmen WHO dan negara-negara anggotanya terhadap infeksi dengue. Dalam resolusi WHA55, WHO mendesak anggotanya membangun dan memperkuat kapasitas sistem kesehatan untuk menejemen, pengawasan, pencegahan, pengendalian dan pengelolaan demam dengue dan demam berdarah dengue. WHO juga mendesak anggotanya agar mendukung pengembangan, aplikasi, evaluasi, dan riset alat-alat dan strategi baru terkait pencegahan dan pengawasan DF dan DHF.
Berdasarkan dampak yang ditimbulkan dari infeksi Virus Dengue dibutuhkan penelitian mengenai protein yang diekspresikan Virus Dengue. Salah satunya adalah protein non-struktural 1 (NS1). Protein ini disekresikan pada serum pasien DBD pada tahap dini [4]. Oleh karena itu dimungkinkan diagnosa penyakit DBD menggunakan kit deteksi dengan protein NS1 sebagai substrat [5].

Penelitian mengenai hubungan filogenetik protein NS1 dari serotipe dengue yang berbeda menjadi sangat penting untuk dilakukan guna mengetahui mutasi-mutasi yang terjadi pada protein ini. Selain itu perbandingan antara urutan asam amino yang menyusun epitop protein NS1 yang bersifat spesifik terhadap salah satu serotipe perlu dilakukan, sehingga memungkinkan prediksi asam amino yang menyusun epitop spesifik protein NS1 dari Virus Dengue tipe tiga yang banyak mengakibatkan kasus infeksi dengue di Indonesia [6]. Informasi mengenai epitop spesifik NS1 Virus Dengue tiga diharapkan dapat bermanfaat untuk perancangan sistem diagnosa Virus Dengue yang dapat mengidentifikasi serotipe Virus Dengue pada serum pasien.

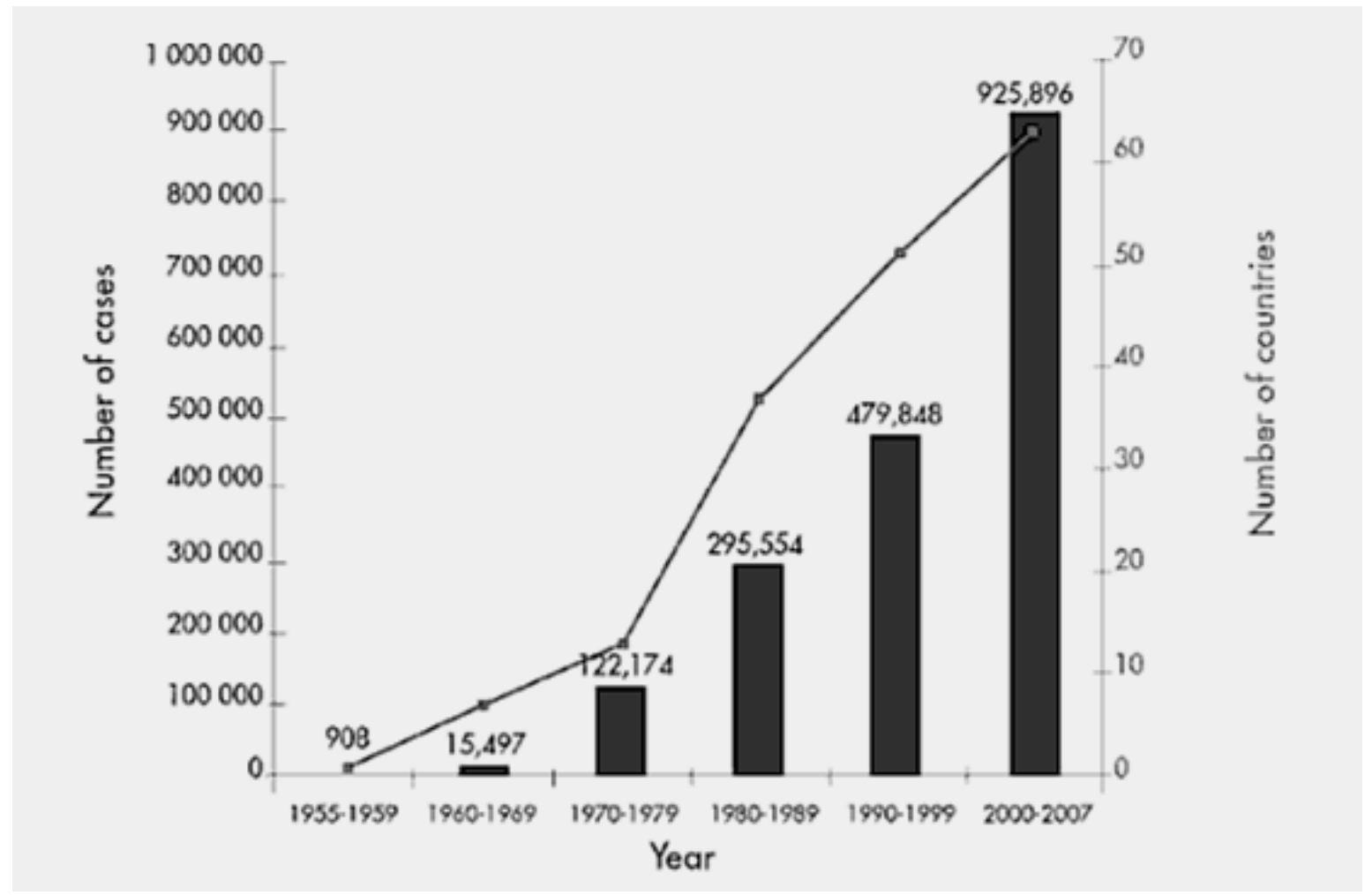

Gambar 1. Angka rata-rata kasus DF dan DHF tiap tahun yang dilaporkan kepada WHO [3], dan jumlah negara yang melaporkan kasus DBD, 1955-2007 


\section{TINJAUAN PUSTAKA}

Virus Dengue yang termasuk dalam genus Flavivirus tampak seperti partikel bola (spherical) berdiameter sekitar $50 \mathrm{~nm}$, dengan selubung lipid yang berasal dari membran sel inang [7]. Virion mengandung inti berupa nukleokapsid yang terdiri dari RNA untai tunggal positif dan beberapa protein kapsid (C) [8]. Genom virus ini terdiri dari 11.000 nukleotida yang mengkode satu ORP (Open Reading Frame) pengkode 10 protein [7]. Protein penyusun Virus Dengue dan kelompok Flavivirus lainnya terdiri atas protein struktural dan nonstruktural. Protein struktural terdiri atas protein $\mathrm{E}$ (Envelope), protein C (Kapsid) dan protein M (Membran). Sedangkan protein nonstruktural meliputi protein NS1, NS2a, NS2b, NS3, NS4a, NS4b dan NS5 [9].

Protein NS1 merupakan glikoprotein dengan berat molekular $42-50 \mathrm{kD}$ yang terdiri dari 353 sampai 354 asam amino [9]. Protein ini memiliki 2 situs glikosilasi-N yang terkonservasi dan 12 residu sistein yang membentuk 6 jembatan disulfida [10]. Selama proses sintesa protein NS1 disisipkan ke dalam retikulum endoplasma dimana protein ini akan membentuk dimer, proses dimerisasi ini mengawali perpindahan protein NS1 ke badan Golgi [11]. Adapun peran utama protein ini terkait dengan proses replikasi RNA virus [4].

Beberapa peneliti telah menemukan epitop pada protein NS1. Contohnya Falconar et al. [12] menemukan fragmen LD2. Antibodi monoklonal dari Virus Dengue 2 pada analisis papscan hanya berikatan dengan fragmen LD2 (asam amino 25-33) dari Virus Dengue 2, meskipun asam amino yang sama dimiliki oleh serotipe dengue lainnya. Hasil yang berbeda ditemukan pada analisis immunoblotting, yang menunjukkan antibodi monoklonal terhadap fragmen LD2 dapat mengenali fragmen LD2 pada serotipe lain. Jiang et al. [13] juga menemukan dua epitop protein NS1 spesifik terhadap Virus Dengue tipe 2, kedua epitop tersebut adalah fragmen PA10 (asam amino 36-45) dan fragmen AA10 (asam amino 187-196). Selain itu $\mathrm{Wu}$ et al. [14] mempelajari epitop pada protein NS1 Virus Dengue tipe satu dan berhasil mendapatkan satu epitop spesifik yaitu fragmen P14M (asam amino 110-117).

\section{METODE PENELITIAN}

\subsection{Sampel}

Sampel berupa sekuen DNA NS1 Virus Dengue 1, 2, 3 dan 4 diperoleh dari genebank (www.ncbi.com), sebanyak 1119 buah sekuen dari sampel kawasan Asia. Analisis dilakukan terhadap 24 buah sekuens DNA NS1 Virus Dengue yang berasal dari Asia Tenggara dan diambil secara acak sebagai representasi dari dari total sekuen DNA NS1 Virus Dengue di kawasan Asia Tenggara.

\subsection{Perangkat Lunak}

Perangkat lunak yang digunakan untuk pengolahan data sekuen asam amino protein NS1 dari berbagai strain Virus Dengue adalah EditSeq dan MegAlign dari Lasergene ${ }^{\circledR}$.

\subsection{Metode Analisis Hubungan Filogenetik Protein NS1}

Open Reading Frame dari sekuen DNA NS1 Virus Dengue 1, 2, 3 dan 4 ini ditentukan dengan mengacu pada Chang [9]. Selanjutnya, data sekuen DNA yang mengkode protein NS1 dimasukkan pada program EditSeq. Data yang terkumpul kemudian diolah untuk memunculkan sekuen asam amino yang dikode dengan program yang sama. Selanjutnya sekuen asam amino yang diperoleh dijajarkan dengan program MegAlign. Setelah proses penjajaran data keseluruhan, pohon filogenetik dapat ditampilkan dengan memilih menu View lalu memilih menu Phylogenetic tree

\subsection{Metode Analisis Perbandingan Asam Amino Penyusun Epitop Serospesifik Protein NS1}

Analisis perbandingan asam amino penyusun epitop serospesifik protein NS1 dilakukan berdasarkan referensi epitop masing-masing serotipe. Pengamatan dilakukan dengan membandingkan urutan asam amino pada fragmen imunogenik suatu serotipe Virus Dengue dengan asam amino pada urutan yang sama dari serotipe Virus Dengue lainnya 


\section{HASIL DAN PEMBAHASAN}

\subsection{Analisis Pohon Filogenetik Protein NS1 dari Virus Dengue di Asia Tenggara}

Hasil analisis pohon filogenetik protein NS1 dari Virus Dengue di Asia Tenggaa dapat dilihat pada gambar 2

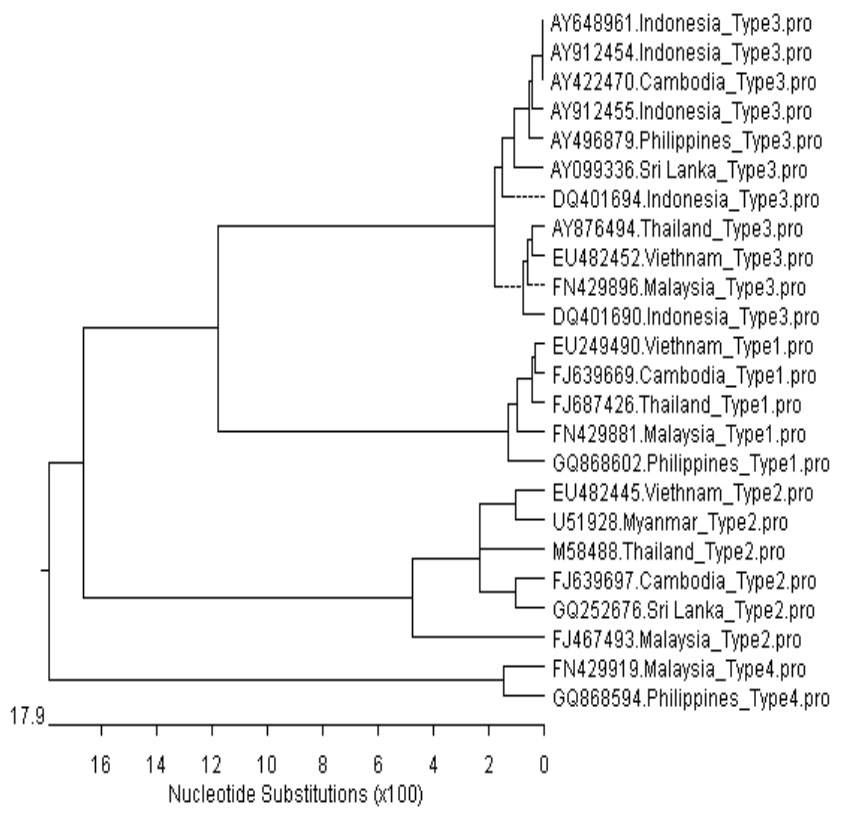

Gambar 2. Pohon filogenetik protein NS1 dari berbagai Virus Dengue di Asia Tenggara

Analisis Analisis sekuen protein NS1 dari sampel virus yang diisolasi di Asia Tenggara menunjukkan pohon filogenetik yang cukup dekat kekerabatannya. Dimana kesamaan sekuen asam amino paling rendah berkisar antara $72 \%$ yang merupakan sekuen protein NS1 dari Malaysia, Viethnam, dan Myanmar. Sementara 21 sekuen asam amino protein lainnya memiliki persentase kesamaan sekuen asam amino antara 91-99\%. Pohon filogenetik yang ditampilkan menunjukkan adanya kelompok-kelompok yang dibentuk oleh masing-masing protein dengue, dengan kelompok protein NS1 dari Virus Dengue tipe 3 berada pada puncak pohon filogenetik. Kemudian kelompok protein NS1 dari Virus Dengue tipe 1 berada dibawahnya, diikuti kelompok Virus Dengue tipe 2 dan kelompok Virus Dengue tipe 4. Berdasarkan struktur pohon filogenetik protein NS1 yang paling dekat kekerabatannya adalah NS1 dari serotipe dengue 3 dan dengue 1 . Sekuen asam amino protein NS1 dari Virus Dengue serotipe 3 dari Indonesia tidak tampak membentuk kluster tersendiri, melainkan bergabung dengan protein NS1 dari Virus Dengue serotipe 3 lainnya.
Kesamaan sekuen asam amino yang begitu tinggi terjadi akibat keberadaan daerah yang terkonservasi pada situs glikosilasi pada protein NS1 [9]. Protein NS1 juga memiliki 12 residu sistein yang terkonservasi dan membentuk 6 jembatan disulfida [10], Dalam penelitian ini kedua belas residu sistein tersebut teridentifikasi berada pada pada asam amino nomor 4, 15, 55, 143, 179, 223, 280, 291, 312, 313, 316 dan 329. Dari ke-24 sekuen protein yang dianalisis tidak ditemukan adanya mutasi pada asam amino sistein tersebut. Keberadaan asam amino ini membuat protein NS1 tak mudah termutasi, tidak seperti protein NS2A, 2B, 4A dan $4 \mathrm{~B}$ yang tidak terkonservasi sehingga cenderung mengalami mutasi [9].

\subsection{Analisis Perbandingan Asam Amino Penyusun Epitop Serospesifik Protein NS1}

Hasil analisis perbandingan epitop serospesifik sampel protein NS1 Virus Dengue dari Asia Tenggara dapat dilihat pada gambar 3 .

\section{VT DE VH T IT T Q Q Y K F Q A D S P K Majority \\ V T N E V H T IT T E O Y K F O A D S P K EU249490.Viethnam_Typel.pro V T D N V H T TI T E O Y K F O P D S P S FJ467493.Malaysia_Type2.pro V T N E V H T UT T E O Y K F Q A D S P K AY648961. Indonesia_Type3.pro V A D N V H T UT T E Q Y K F O P E S P A FN429919. Malaysia_Type4.pro \\ A. Fragmen LD2}

A D S P KR L A S A I XKA H R S T Majority

$40 \quad 50 \quad 60$

A $D$ D S P K R L S A A I G K A W $\mathrm{R}$ S A EU249490. Viethnam_Typel.pro

$P$ D S P S K L A S A I O K A H R S V FJ 467493.Malaysia_Type2.pro

A D S P KR L A T A I A G A UT $R$ S $T$ AY648961.Indonesia_Type3.pro

P E S P A R L A S A I L N A H R S T FN429919.Malaysia_Type4.pro

B. Fragmen PA10

110

120

K K M I R P O P M E Y K Y S W K S WT G K EU249490.Viethnam_Typel.pro K R S L K P Q P V E L R Y S W K S W G K FJ467493.Malaysia_Type2.pro K R T L T P Q P M E L K Y \$ W K T W G K AY648961. Indonesia_Type3.pro K R A L T P P V N D L K Y S W K T Wi G K FN429919.Malaysia_Type4.pro

\section{Fragmen P14M}

H R L M S A A V K D X K A VH A D M G Y Majority

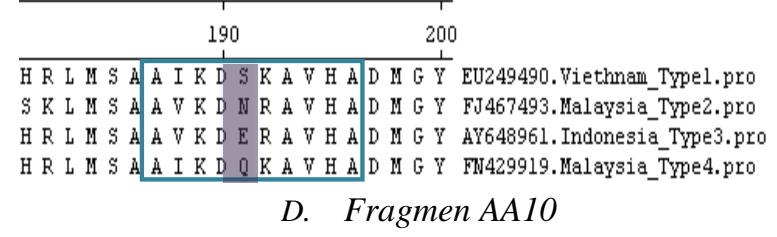

Gambar 3. Perbandingan urutan asam amino pada fragmen imunogenik yang telah dikonfirmasi dari masing-masing strain. A. Fragmen LD 2 [7] epitop spesifik DEN-2; B. Fragmen PA10 [9] epitop spesifik DEN-2; C. Fragmen P14M [16] epitop spesifik DEN-1; dan D. Fragmen AA10 [9] epitop spesifik DEN-2 
Berdasarkan hasil perbandingan asam amino dari masing-masing serotipe pada fragmen imunogenik yang telah dilaporkan, tampak bahwa pada fragmen LD2 yang merupakan epitop spesifik NS1 DEN-2 [12] tidak terjadi mutasi asam amino. Sementara pada fragmen PA10 dan AA10 [13] sebagai epitop spesifik protein NS1 DEN-2 terdapat mutasi asam amino. Kemudian pada epitop serospesifik DEN-1 yaitu fragmen P14M [14] juga ditemukan mutasi.

Berdasarkan hasil perbandingan sekuens asam amino ditemukan sejumlah kecil perbedaan asam amino pada fragmen-fragmen imunogenik dari protein NS1 pada Virus Dengue 2. Pada fragmen LD2 yang dilaporkan oleh Falconar et al. [12] tidak ada perbedaan urutan asam amino antara tipe Virus Dengue yang satu dan lain. Sementara pada fragmen PA10 yang oleh Jiang et al. [13] teridentifikasi terdiri atas asam amino PESPSKLASA pada sampel dalam penelitian ini terdiri atas asam amino PDSPSKLASA. Mutasi terjadi pada asam amino E (asam glutamat) yang berubah menjadi asam amino $\mathrm{D}$ (asam aspartat) tetapi mutasi ini diprediksi tidak terlalu berpengaruh karena keduanya asam amino dikarboksilat. Hasil pensejajaran fragmen PA10 Virus Dengue 2 dengan Virus Dengue lainnya menunjukkan adanya mutasi yang mengakibatkan perbedaan jumlah asam amino serin. Pada Virus Dengue 2 terdapat tiga buah asam amino serin, sedangkan akibat mutasi hanya terdapat dua buah asam amino serin pada Virus Dengue tipe 1 dan 4 serta sebuah serin pada Virus Dengue tipe 3. Mutasi yang terjadi pada asam amino serin ini dapat menjadi penyebab fragmen PA 10 Virus Dengue 2 lebih reaktif dibandingkan serotipe lain, dengan kemungkinan asam amino serin mengakibatkan konformasi protein NS1 dari dengue 2 berbeda dari Virus Dengue lain. Asam amino serin akan mengalami fosforilasi dan berperan dalam regulasi aktivitas protein serta proses transduksi sinyal [15].

Fragmen P14M (EYKYSWKS) yang merupakan epitop spesifik Virus Dengue 1, mengalami mutasi spesifik pada asam amino ke 111. Pada Virus Dengue 1 asam amino ke 111 merupakan tirosin sementara pada protein NS1 Virus Dengue lain asam amino ke 111 adalah leusin. Mutasi lain pada fragmen ini terjadi pada asam amino ke 112 dan 117 tetapi mutasi ini tidak bersifat spesifik hanya pada Virus Dengue tipe 1, melainkan terjadi pula pada Virus Dengue lainnya. Wu et al. [14] pada fragmen P14M memiliki asam amino dengan urutan yang berbeda yaitu EHKYSWKS. Pada fragmen P14M tersebut asam amino kedua adalah histidin sedangkan pada sampel dalam penelitian ini adalah tirosin untuk Virus Dengue 1 dan leusin untuk Virus Dengue tipe lainnya. Wu et al. kemudian melakukan penelitian yang menunjukkan bahwa penggantian asam amino histidin dengan leusin akan menurunkan kemampuan fragmen ini berikatan dengan antibodi monoklonal. Sedangkan untuk asam amino tirosin, merujuk pada Walsh et al. [16] tirosin memiliki peran yang sama seperti histidin, yaitu dalam proses fosforilasi, sehingga diprediksi bahwa mutasi protein histidin dengan tirosin tidak berpengaruh signifikan terhadap fragmen P14M.

Pada fragmen AA10 mutasi spesifik dengue 2 terjadi pada basa ke 191. Pada Virus Dengue dua, asam amino ke 191 merupakan asam amino aspargin, sedangkan pada Virus Dengue lain berupa asam amino serin dan asam glutamat. Asam amino aspargin berperan dalam regulasi protein [15] sehingga kemungkinan mempengaruhi struktur 3-D fragmen AA10 pada Virus Dengue dua dan mengakibatkannya dikenali oleh antibodi.

\section{KESIMPULAN}

Berdasarkan hasil analisis pohon filogenetik protein NS1 dari berbagai sampel gen NS1 di kawasan Asia Tenggara diketahui bahwa presentase kemiripan sekuan asam amino protein NS1 sampel tinggi (72-99\%). Selain itu masing-masing serotipe Virus Dengue membentuk klaster tersendiri pada pohon filogenetik. NS1 dari serotipe dengue 3 dan dengue 1 memiliki kekerabatan paling dekat, disusul dengan dengue 2. Dengue 4 memiliki kluster tersendiri yang terpisah dari dengue 1, 2, dan 3 .

Berdasarkan hasil analisis perbandingan fragmen imunogenik dari Virus Dengue tipe 1 dan tipe 2 diketahui bahwa pada fragmen LD 2 dari tipe Virus Dengue yang berbeda tidak terdapat perbedaan asam amino. Pada fragmen PA 10 jumlah asam amino serin paling banyak terdapat pada Virus Dengue 2. Fragmen AA 10 Virus Dengue tipe 2 memiliki aspargin sebagai asam amino ke 191, sementara pada Virus Dengue tipe lain memiliki asam amino lain. Fragmen P14M Virus Dengue tipe 1 memiliki tirosin di posisi asam amino ke 111, sementara pada Virus Dengue lain memiliki leusin di posisi asam amino tersebut. Perbedaanperbedaan asam amino ini diperkirakan mengakibatkan perubahan karakteristik protein 
NS1 sehingga mempengaruhi imunogenitas dari masing-masing galur Virus Dengue

\section{UCAPAN TERIMA KASIH}

Terima kasih kepada Dr. Ary Syahriar selaku Dekan FST dan kepada Dr. Nita Noriko selaku Kepala Program Studi Biologi, FST, Universitas Al Azhar Indonesia.

\section{DAFTAR ACUAN / PUSTAKA}

[1] Arvin, Behrman Kliegman. Ilmu Kesehatan Anak, dalam Wahab, A. Simak (Ed). Penerbit Buku Kedokteran (ECG): Jakarta. 2000.

[2] Chakraborty, Tirtha. Deadly Diseases and Epidemics: Dengue Fever and Other Hemorrahgic Viruses. Infobase Publishing: New York. 2008.

[3] WHO. Dengue: Guidelines for Diagnosis, Treatment, Preventation and Control. World Health Organization: Prancis. 2009.

[4] Tajima, S., Tomohiko Takasaki dan Ichiro Kurane. Characterization of Asn130-toAla mutant dengue type 1 virus NS1 protein. Virus Genes Volume 36. Springer. Hlm 323-329. 2008.

[5] Endy, T. P., et al. Diagnosis of Dengue Virus Infection, dalam Halstead, Scott B. (Ed.), Dengue. Imperail College Press: London. hlm 327-360.

[6] Guzman, M.G. dan Gustavo K. Dengue diagnosis, advances and challenges. International Journal of Infectious Diseases Volume 8. hlm 69-80. 2003.

[7] Beasley, David W. C. and Barret, Alan D. T.. The Infectious Agent, dalam Halstead, Scott B. (Ed.), Dengue. Imperail College Press: London. hlm 29. 57. 2008.

[8] Lindenbach, B.D, Heinz-JüRGEN Thiel dan Charles M. Rice. Flaviviridae: The Viruses and Their Replication. Dalam D. M. Knipe dan P.M. Howley (Eds.), Fields Virology. Lippicott-Raven Publishers: Philadelphia. hlm 1101-1152. 2007.
[9] Chang, G.-J. Molecular biology of dengue viruses, dalam Gubler, D. J dan G. Kuno (Ed). Dengue and Dengue Hemorrhagic Fever. CAB International: US. hlm 175-198. 1997.

[10] Chambers, T.J., C.S. Hahn, R. Galler, dan C.M. Rice. Flavivirus genome organization, expression, and replication. Annual Review Microbiol Volume 44. hlm 649-688. 1990.

[11] Winkler, G., S. E. Maxwell, C. Ruemmler, dan V. Stollar. Newly synthesized dengue-2 virus nonstructural protein NS1 is a soluble protein but becomes partially hydrophobic and membraneassociated after dimerization. Journal of Virology Volume 171. hlm 302-305. 1989.

[12] Falconar, A. K. I., P. R. Young dan M. A. Miles. Precise location of sequential dengue virus subcomplex and complex B cell epitopes on the nonstructural-1 glycoprotein. Archives of Virology Volume 137. hlm 315-326. 1994

[13] Jiang, Lan, Jun-Mei Zhou, Yun Yin, Dan-Yun Fang, Yun-Xia Tang, Li-Fang Jiang. Selection and identification of B-cell epitope on NS1 protein of dengue virus type 2. Virus Research Volumr 150 hlm 49-55. 2010.

[14] Wu, Han-Chung, Yue-Ling Huang, Ting-Ting Chao, Jia Tsrong Jan, Jau-Ling Huang, Hsien-Yuan Chiang, Chwan-Chuen King dan Men-Fang Shaio. Identification of B-Cell Epitope of Dengue Virus Type 1 and Its Application in Diagnosis of Patients. Journal of Clinical Microbiology Volume 39. Hlm 977-982. 2001

[15] Seao, Jawon dan Kong-Joo Lee. Post-translational modifications and their biological functions: Proteomic analysis and systematic approaches. Journal of Biochemistry and Molecular Biology Volume 37. Hlm 35-44. 2004.

[16] Walsh, C.T, S.G Tsodikova dan G.J. Gatto, Jr Protein Posttranslational Modifications: The Chemistry of Proteome Diversification (Review). Angewndte Chemie International Volume 44. Hlm 7342-7372. 2005. 